\title{
Protein and mRNA expression of estradiol receptors during estrus in yaks (Bos grunniens)
}

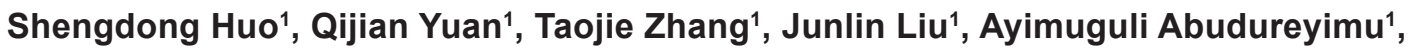 \\ Jutian Yang ${ }^{1}$
}

\footnotetext{
${ }^{1}$ Northwest University for Nationalities, Lanzhou, Gansu, China.
}

ABSTRACT - The objective of this study was to investigate mRNA by real-time PCR and protein expression by immunofluorescence of the estradiol receptors (ER) in the pineal gland, hypothalamus, pituitary gland, and gonads of yaks (Bos grunniens). The analysis showed that the level of expression of ER mRNA was greater in the pituitary gland tissue than in other glands during estrus. Immunofluorescence analyses showed that ER proteins were located in the pineal cells, synaptic ribbon, and synaptic spherules of the pineal gland. In the hypothalamus, ER proteins were located in the magnocellular and parvocellular neurons. The ER proteins were located in acidophilic cells and basophilic cells in the pituitary gland. In the ovary, ER proteins were present in the ovarian follicle, corpus luteum and Leydig cells. Estradiol exerts its main effects on the pituitary gland during estrus in yak.

Key Words: immunofluorescence, real-time PCR

\section{Introduction}

The yak (Bos grunniens) must be regarded as one of the world's most remarkable domestic animals because it thrives in conditions of extreme harshness and deprivation while providing a livelihood for people (Wiener et al., 2003). The yak is a typical animal of the Qinghai-Tibetan Plateau and has a seasonal estrus. The breeding season begins in July and ends in March of the Qinghai-Tibetan Plateau, and is regulated by melatonin (Huo and Long, 2014). Estradiol has a very important role during the breeding season because it is responsible for the health of oocytes and ovarian follicles (Ireland et al., 2009). Estradiol provides relatively high numbers of follicles, which enhance ovarian function and fertility in cattle (Erickson, 1966; Erickson et al., 1976; Cushman et al., 1999; Taneja et al., 2000; Oliveira et al., 2002; Singh et al., 2004). However, the mechanisms underlying the inherently high efficiency of estrus and folliculogenesis in yak are poorly understood.

Our objectives were to determine the pathway of action of estradiol in the pineal gland-hypothalamus-pituitary-

Received March 27, 2015 and accepted August 21, 2015.

Corresponding author: huoshd12@lzu.edu.cn

http://dx.doi.org/10.1590/S1806-92902015001000002

Copyright ( $) 2015$ Sociedade Brasileira de Zootecnia. This is an Open Access article distributed under the terms of the Creative Commons Attribution License (http://creativecommons.org/licenses/by/4.0/), which permits unrestricted use, distribution, and reproduction in any medium, provided the original work is properly cited. gonadal axis and to measure the level of estradiol in the pineal gland, hypothalamus, pituitary, and gonads during estrus.

\section{Material and Methods}

Tissue samples from the pineal gland, hypothalamus, pituitary gland, and ovary of yaks were obtained at the time of slaughter, and were stored immediately in a RNAlater (Omega Bio-tek Inc., Norcross, GA, USA) solution and paraformaldehyde until further use. Samples were collected in a slaughterhouse of Tianzhu County from six female yaks (in estrus) in October 2012, during the breeding season.

Total tissue RNA was extracted using RNAiso Plus (Takara Bio Inc., Dalian, China) and the quality was checked by monitoring the A260/280 absorbance ratio, which was within the 1.9 to 2.0 range by Ultraviolet Spectrophotometer (Eppendorf Bio-tek Inc., Hamburg, Germany). Reverse transcription was performed using the ABI Veriti96 PCR (Applied Biosystems Inc., Carlsbad, AR, USA). Each $10-\mu \mathrm{L}$ reaction consisted of $2 \mu \mathrm{L}$ PrimeScript RT Master Mix Perfect Real Time $(5 \times)$ (Perfect Real Time; Takara Bio Inc., Dalian, China) reagent kit, with $2.0 \mu \mathrm{L}$ of template RNA, and $6 \mu \mathrm{L}$ RNase-free $\mathrm{H}_{2} \mathrm{O}$. The parameters were $37{ }^{\circ} \mathrm{C}$ for $15 \mathrm{~min}$ and $85^{\circ} \mathrm{C}$ for $5 \mathrm{~s}$.

To compare estrogen receptor (ER) mRNA expression in different yak tissues (pineal gland, hypothalamus, pituitary gland, and ovary) during the breeding season, a real-time PCR assay was performed using the SYBR Premix 
Ex TaqTM II (Perfect Real Time; Takara Bio Inc., Dalian, China) reagent. The $18 \mathrm{~S}$ was used as a housekeeping gene to correct potential variations in the RNA loading. The primers were designed using the Primer Premier software (version 6.0; Premier Biosoft International, Palo Alto, CA, USA), and were based on the mRNA sequence of ER. The primers used for ER were 5'- GGAAGTGCTATGAGGTTGGAATG -3' (forward) and 5'- TCCACCGTTCCTCTTGGTTT $3^{\prime}$ (reverse). The primers used for the $18 \mathrm{~S}$ plasmid were 5'- ACGGACAGGATTGACAGA-3' (forward) and 5'TCGCTCCACCAACTAAGA-3' (reverse).

Real time (RT) polymerase chain reaction (PCR) was performed using the ABI PRISM 7500 Real Time PCR system (Applied Biosystems Inc., Carlsbad, AR, USA). Each $25-\mu \mathrm{L}$ reaction consisted of $12.5 \mu \mathrm{L}$ SXBR Premix Ex TaqTM II (2×) (Perfect Real Time; Takara Bio Inc., Dalian, China) reagent kit, $2 \mu \mathrm{L}$ of the cDNA sample, with $1.0 \mu \mathrm{L}$ of each primer $(10 \mu \mathrm{mol} / \mathrm{L}$; forward and reverse), and $8.5 \mu \mathrm{L}$ deionized $\mathrm{H}_{2} \mathrm{O}$. The PCR parameters were $50{ }^{\circ} \mathrm{C}$ for $2 \mathrm{~min}, 95^{\circ} \mathrm{C}$ for $5 \mathrm{~min}, 95^{\circ} \mathrm{C}$ for $10 \mathrm{~s}$, and $60{ }^{\circ} \mathrm{C}$ for $30 \mathrm{~s}$. The cycle threshold $(\mathrm{Ct})$ was returned to baseline during each reaction. Based on the melting curve, we determined whether a specific product or a primer dimer was present in the PCR during each reaction.

The standard curves were generated from a standard sample, i.e., a 10 -fold serial dilution (from $10^{1}$ to $10^{6}$ ). The standard curve parameter calculations were used to determine the correlation coefficient: $\mathrm{R}_{E R}^{2}=0.992$, slope $=$ -3.939 , intercept $=30.189 ; \mathrm{R}^{2}{ }_{185}=0.999$, slope $=-3.451$, intercept $=27.267$. Each sample was tested in triplicate.

An immunohistochemical assay was developed to study ER protein expression in yak tissues (pineal gland, hypothalamus, pituitary gland, and ovary) during the breeding season. The tissues were embedded in paraffin and dehydrated. The ER protein expression was analyzed using an SP immunohistochemistry kit (Maixin, Fuzhou, China). The primary antibody was a rabbit polyclone antibody against ER and was used at 1:100 dilutions. Briefly, after deparaffinization, the slides were pretreated with hot $0.02 \mathrm{M}$ PBS for 10 min for antigen unmasking and followed by pre-primary antibody peroxidase inhibition. The slides were then incubated with the estrogen receptor antibody at $37^{\circ} \mathrm{C}$ for $2 \mathrm{~h}$.

The relative ER mRNA expressions were analyzed in pineal gland, hypothalamus, pituitary gland, and ovary. The data were expressed as the mean \pm SD. The SPSS 15.0 (SPSS Inc., Chicago, IL, USA) software was used to analyze the data. The following statistical model was used:

$$
\mathrm{y}_{\mathrm{ij}}=\mu+\alpha_{\mathrm{i}}+\mathrm{e}_{\mathrm{ij}} \text {, }
$$

in which $y_{i j}$ is the expression measured in the $\mathrm{j}$-th animal of the i-th ER mRNA. Significant differences were determined using protected Tukey test $(\mathrm{P} \leq 0.05)$ after the one-way ANOVA.

\section{Results}

During the estrus in the yak, levels of ER mRNA expression were greater $(\mathrm{P}<0.01)$ in hypothalamic tissue when compared with pineal and pituitary glands and ovary (Figure 1). It was also greater $(\mathrm{P}<0.05)$ in the pituitary gland and ovary than in the pineal gland.

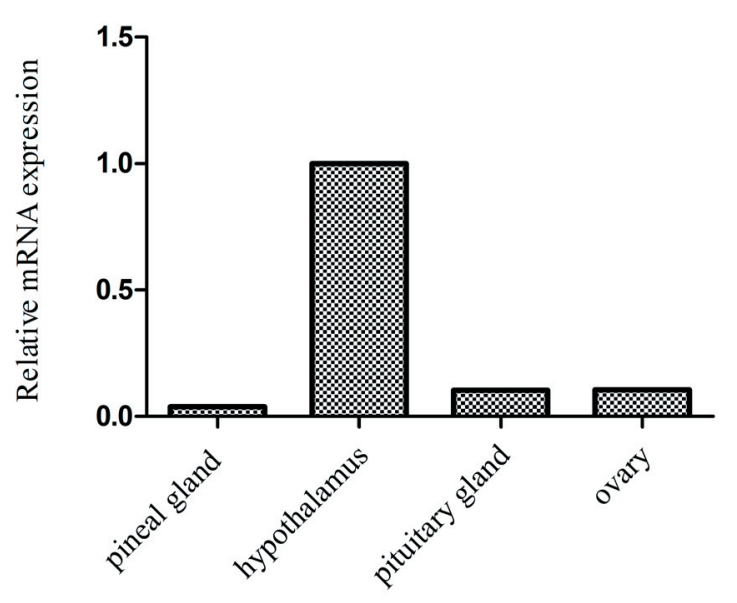

Values are normalized to the values for 18s. Each sample was analyzed in triplicate.

Figure 1 - ER mRNA expression in the pineal gland, hypothalamus, pituitary gland, and ovarian tissues of yak during estrus $(\mathrm{n}=6)$ as determined by real-time PCR.

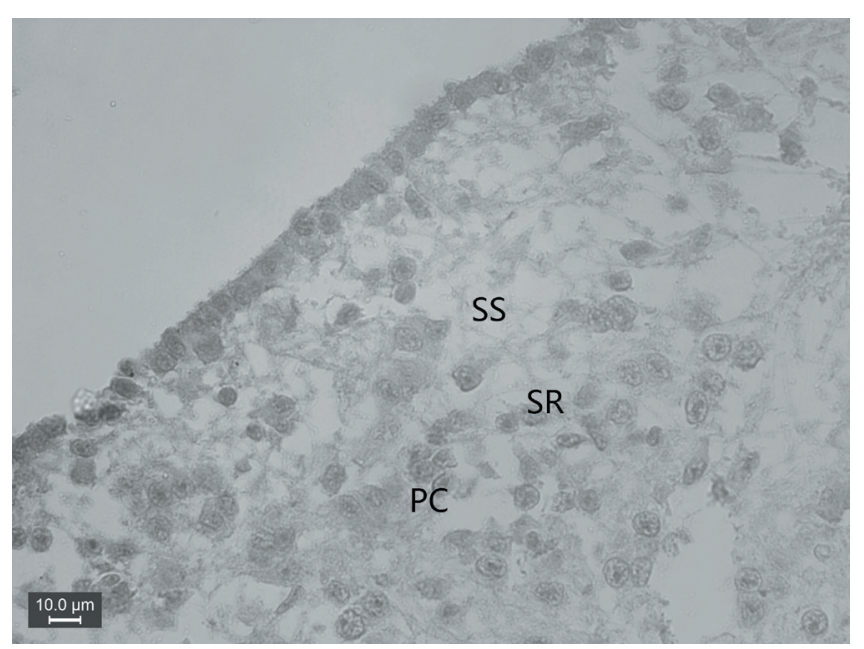

Figure 2 - Expression of ER protein in pineal gland tissue of the yak during estrus $(n=6)$ as determined by immunofluorescence. The pineal gland, pineal cell (PC), synaptic ribbon (SR), and synaptic spherules (SS) contained receptors for $\mathrm{E}$. 
The pineal gland is the main tissue in which melatonin is produced. The ER protein was expressed in the pineal cells, synaptic ribbon (SR), and synaptic spherules (SS) of the pineal gland (Figure 2). The ER protein expression was detected in magnocellular and parvocellular neurons in hypothalamic tissue during estrus in the yak during estrus (Figure 3). The ER protein was detected in $\alpha$ cells and $\beta$ cells of the pituitary gland in the yak during estrus (Figure 4). The ER protein was detected in ovarian follicles, granular leukocytes and oocytes within the ovary (Figures 5A and 5B).

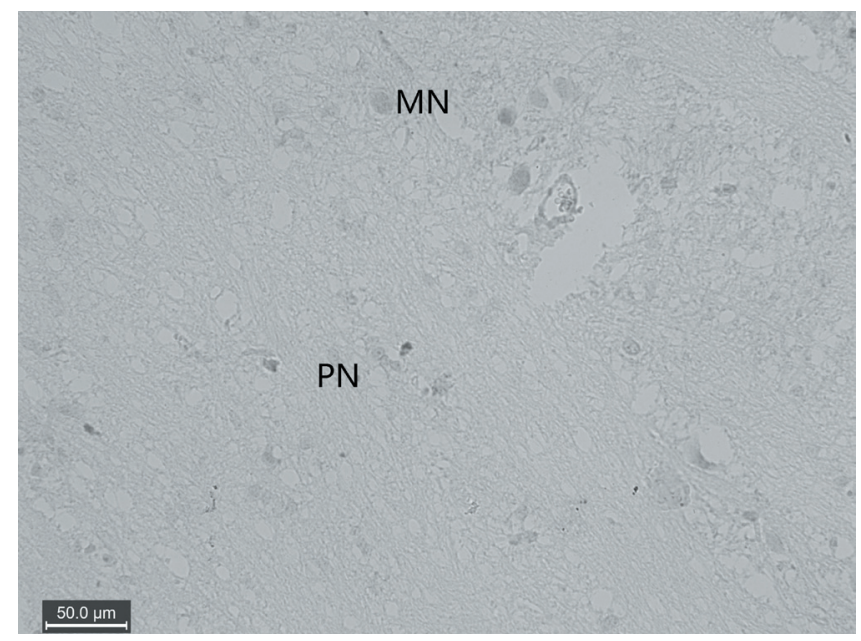

Figure 3 - Expression of ER protein in the magnocellular neurons $(\mathrm{MN})$ and parvicellular neurons $(\mathrm{PN})$ of the hypothalamus tissue of female yaks in estrus $(n=6)$ as determined by immunofluorescence.

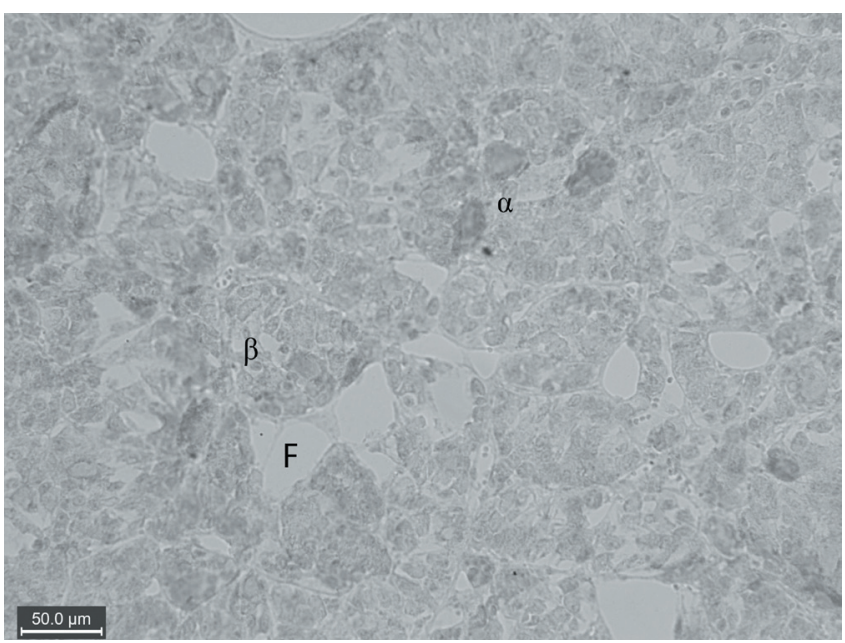

The colloid was lost in the folliculi (F).

Figure 4 - Expression of ER protein in $\alpha(\alpha)$ and $\beta(\beta)$ cells of the pituitary gland in female yaks in estrus $(n=6)$.
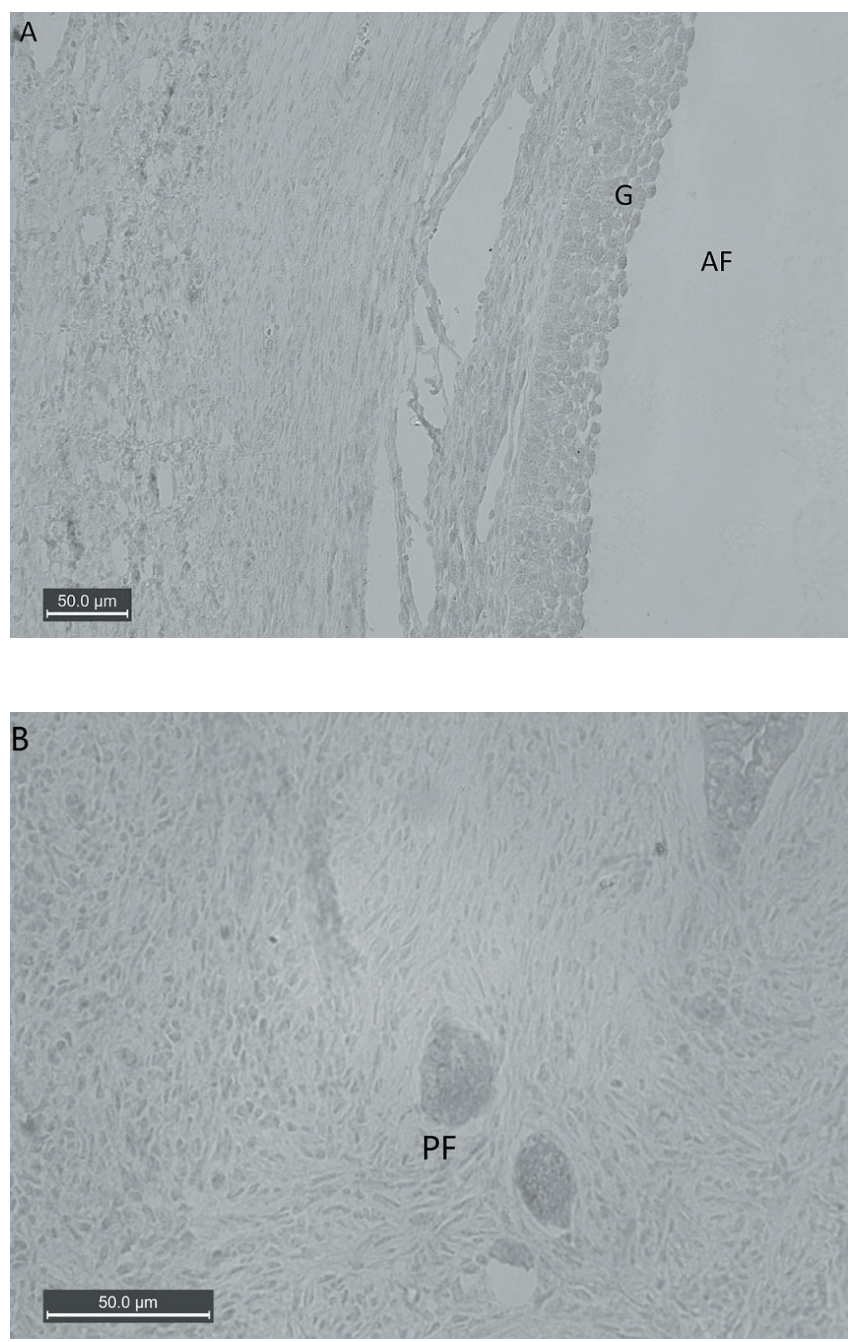

Figure 5 - Expression of ER protein in antrum of follicle (AF), primordial follicle $(\mathrm{PF})$, and granulocyte $(\mathrm{G})$ of the ovary in female yaks in estrus $(n=6)$.

\section{Discussion}

The most significant results of the present study demonstrated, for the first time in the yak, that estradiol receptor (ER) mRNA is at the highest level in the hypothalamus and that the ER protein is expressed in the pineal gland, hypothalamus, pituitary, and ovary. It is important to emphasize that the release of gonadotropinreleasing hormone is controlled mainly by the level of estradiol during estrus. The signal of the beginning of estrus is transmitted to the hypothalamus by estradiol. Subsequently, GnRH is released into the hypophyseal portal system from the neurons. In the yak, GnRH stimulates the pituitary and ovary to regulate estrus through FSH, LH, E, and $\mathrm{P}_{4}$.

Melatonin is the main factor that initiates estrus during the breeding season of the yak (Huo and Long, 2014), and 
is involved in the control of reproduction (DeNicolo et al., 2008; Martinez-Royo et al., 2012). The ER located SR and SS of the pineal gland (Figure 2). Estradiol valerate prevents ovulation by inducing atresia of the potential preovulatory follicle, which is replaced by a healthy large follicle by 14 days post-treatment in dairy cattle (Engelhardt et al., 1989). A significant positive correlation was found to exist between corpora lutea numbers and each of the ova/embryo parameters and the estradiol levels in estrus (Savage et al., 1987). The ER mRNA expression is high (Figure 1) in the hypothalamus during GnRH release. GnRH regulates the levels of LH and FSH in the anterior pituitary during estrus in the yak, and estradiol increases soluble guanylyl cyclase in the anterior pituitary at this time (Cabilla et al., 2009). The neuropeptide pituitary adenylate cyclase activating polypeptide is involved in estrus (Moore et al., 2005). Estradiol stimulates the formation of gap junctions and proliferation of granulosa cells, and also enhances the action of FSH and LH in the ovary (Bauer-Dantoin et al., 1993; Armstrong and Childs, 1997). The expression of the gene ESR36 is directly regulated by FSH and LH, while ovarian steroid hormones have a negligible role (Chakraborty and Roy, 2013).

Taken together, these findings provide important evidence that potentially significant physiological differences exist in gene expression related to estradiol during estrus in the yak. Estradiol acts on the hypothalamus, pituitary, and ovary during estrus and regulates the release of hormones to alter the progression of estrus in this species. Estradiol mainly promotes GnRH release from nerves to the pituitary, and subsequently FSH and LH increase in the pituitary. Finally, FSH and LH play a role in follicular growth, ovulation, and stimulation of ovarian hormone release.

\section{Conclusions}

Estradiol mainly enters the hypothalamus to regulate the GnRH, and also acts on the pituitary gland and ovary, where it regulates the hormones produced in the yak of the Qinghai-Tibetan Plateau during estrus.

\section{Acknowledgments}

Financially supported by the National Natural Science Foundation of China (No. 31260589).

\section{References}

Armstrong, J. and Childs, G. V. 1997. Changes in expression of epidermal growth factor receptors by anterior pituitary cells during the estrous cycle: cyclic expression by gonadotropes. Endocrinology 138:1903-1908.

Bauer-Dantoin, A. C.; Hollenberg, A. N. and Jameson, J. L. 1993. Dynamic regulation of gonadotropin-releasing hormone receptor mRNA levels in the anterior pituitary gland during the rat estrous cycle. Endocrinology 133:1911-1914.

Cabilla, J. P.; Ronchetti, S. A.; Nudler, S. I.; Miler, E. A.; Quinteros, F. A. and Duvilanski, B. H. 2009. Nitric oxide sensitive-guanylyl cyclase subunit expression changes during estrous cycle in anterior pituitary glands. American Journal of Physiology - Endocrinology and Metabolism 296:E731-737.

Chakraborty, P. and Roy, S. K. 2013. Expression of estrogen receptor alpha 36 (ESR36) in the hamster ovary throughout the estrous cycle: effects of gonadotropins. PLoS One 8:e58291.

Cushman, R. A.; DeSouza, J. C.; Hedgpeth, V. S. and Britt, J. H. 1999. Superovulatory response of one ovary is related to the micro- and macroscopic population of follicles in the contralateral ovary of the Cow. Biology of Reproduction 60:349-354.

DeNicolo, G.; Morris, S. T.; Kenyon, P. R.; Morel, P. C. and Parkinson, T. J. 2008. Melatonin-improved reproductive performance in sheep bred out of season. Animal Reproduction Science 109:124-133.

Engelhardt, H.; Walton, J. S.; Miller, R. B. and King, G. J. 1989. Estradiol-induced blockade of ovulation in the cow: effects on luteinizing hormone release and follicular fluid steroids. Biology of Reproduction 40:1287-1297.

Erickson, B. H. 1966. Development and senescence of the postnatal bovine ovary. Journal of Animal Science 25:800-805.

Erickson, B. H.; Reynolds, R. A. and Murphree, R. L. 1976. Ovarian characteristics and reproductive performance of the aged cow. Biology of Reproduction 15:555-560.

Huo, S. D. and Long, R. J. 2014. Melatonin receptor (MTNR1A and MTNR2B) expression during the breeding season in the yak (Bos grunniens). Czech Journal of Animal Science 59:140-145.

Ireland, J. J.; Zielak-Steciwko, A. E.; Jimenez-Krassel, F.; Folger, J.; Bettegowda, A.; Scheetz, D.; Walsh, S.; Mossa, F.; Knight, P. G.; Smith, G. W.; Lonergan, P. and Evans, A. C. 2009. Variation in the ovarian reserve is linked to alterations in intrafollicular estradiol production and ovarian biomarkers of follicular differentiation and oocyte quality in cattle. Biology of Reproduction 80:954-964.

Martinez-Royo, A.; Lahoz, B.; Alabart, J. L.; Folch, J. and Calvo, J. H. 2012. Characterisation of the Melatonin Receptor 1A (MTNR1A) gene in the Rasa Aragonesa sheep breed: association with reproductive seasonality. Animal Reproduction Science 133:169-175.

Moore, J. P.; Jr.; Burger, L. L.; Dalkin, A. C. and Winters, S. J. 2005. Pituitary adenylate cyclase activating polypeptide messenger RNA in the paraventricular nucleus and anterior pituitary during the rat estrous cycle. Biology of Reproduction 73:491-499.

Oliveira, J. F.; Neves, J. P.; Moraes, J. C.; Gonçalves, P. B.; Bahr, J. M.; Hernandez, A. G. and Costa, L. F. 2002. Follicular development and steroid concentrations in cows with different levels of fertility raised under nutritional stress. Animal Reproduction Science 73:1-10.

Savage, N. C.; Howell, W. and Mapletoft, R. J. 1987. Superovulation in the cow using estradiol 17beta or GnRH in conjunction with FSH-P. Theriogenology 27:383-394.

Singh, J.; Dominguez, M.; Jaiswal, R. and Adams, G. P. 2004. A simple ultrasound test to predict the superstimulatory response in cattle. Theriogenology 62:227-243.

Taneja, M.; Bols, P. E.; Van de Velde, A.; Ju, J. C.; Schreiber, D.; Tripp, M. W.; Levine, H.; Echelard, Y.; Riesen, J. and Yang, X. 
2000. Developmental competence of juvenile calf oocytes in vitro and in vivo: influence of donor animal variation and repeated gonadotropin stimulation. Biology of Reproduction 62:206-213.
Wiener, G.; Jianlin, H. and Ruijun, L. 2003. Origins, domestication and distribution of yak. p.1-13. In: The yak. 2nd ed. The Regional Office for Asia and the Pacific of the Food and Agriculture Organization of the United Nations, Bangkok. 